\title{
Conversion Efficiency and Economics of Urban Wood Utilization
}

\author{
Craig A. Tinus and Michael LaMana
}

\begin{abstract}
Because of changes in land-use zoning, many standard forest management activities are no longer possible in urban and suburban woodland properties being developed. This trend has created an influx of wood fiber into municipal landfills at significant cost to both landowners and municipalities. An alternative to landfill or other off-site disposal was evaluated that returned wood products to the landowner in a fee-for-service business model. Additionally, the cost for removal was modeled in comparison to the potential value of the wood as lumber. In a case study, the overall average marginal difference to the landowner for material removal was a cost of USD \$35 from all job sites $(\mathrm{n}=21)$; which was essentially break-even. This approach was cost competitive with landfill disposal, and landowners were able to benefit from wood products derived from trees that were being removed because of site development. Additionally, these landowners were preferentially choosing a form of material recycling that likely reduced the load to municipal waste disposal sites, and as such was a benefit to the community

Key Words. Avoided Disposal; Hedonic Valuation; Log; Lumber; Municipal; Recycling; Sawmill; Wood Waste.
\end{abstract}

Significant amounts of wood volume requiring management is found in urban, and increasingly geographically diffuse suburban, areas the northeastern United States (McPherson et al. 2005). In many communities, urban trees are considered beneficial (Gorman 2004; McPherson et al. 2005) and this is reflected in the prevalence of tree preservation ordinances. In addition to urban trees, changes in zoning have created small wooded property lots where traditional tree harvesting techniques are either impractical or not allowed. However, typical site preparation for development creates significant volumes of wood waste products that are typically diverted to landfill sites.

Urban and suburban landowners often favor de facto street tree preservation as well as minimal, selective harvest opportunities of small woodlots for both practical and social reasons (Sabor et al. 2003). These trends are increasing the number and volume of trees comprising the urban forest, and are likely to continue because of both local interests and in creating carbon-offsets (Pataki et al. 2006) and forest conservation.

The highly valued urban forest does provide many benefits, but at a cost. One direct cost to communities and other landowners is disposal, when trees need to be removed. Direct costs for disposal of unwanted woody materials are often significantly greater because of large, log-sized trunk wood. However, disposal of this trunk wood underutilizes a potential resource. Harvested urban trees offer potential commodity-yield, even considering the potential presence of defects and contaminants and wide geographical distribution. Recovery of value-added forest products is economically feasible and of interest to both property owners and public institutions, particularly those with education and outreach as part of mandates or mission statements (unpublished data). For example, previous authors have qualitatively documented a variety of creative approaches to the utilization of wood from harvested urban and suburban trees (Cesa et al. 1994; Lempicki and Cesa 2000; Bratkovich 2001; Sherrill 2003). Many of the urban wood recovery and utilization strategies these authors described have been implemented in differing locales and over different timeframes. However, the operational and economic efficiency of such operations is poorly understood. Broader adoption of, and investment in, urban tree utilization operations arelikely toincrease if they are consistently costeffective.

Researchers analyzed data from Citilog, Inc., an urban tree utilization and secondary processing company based in northern New Jersey, U.S. Using data from sites in the District of Columbia, Maryland, New Jersey, New York, Pennsylvania, and Virginia, U.S., researchers evaluated selected elements of the urban-log recovery process with the following objectives: 1) to document the lumber recovery factor (LRF) and contamination prevalence of logs derived from harvested urban trees that would have otherwise been disposed of as waste or used as a source of firewood and landscape mulch; 2) determine whether recovery of forest products, such as lumber from study logs, was profitable as a stand-alone endeavor, or whether milling of study logs was subsidized by values added by upstream and downstream processes; and 3) quantify the value of avoided disposal (e.g., waste hauling and landfill tipping fees) and to determine the degree to which such avoided tree disposal costs were a functional subsidy to utilization and processing of urban logs.

\section{MATERIALS AND METHODS}

For all study sites, a fee-for-service model was used wherein customers retained ownership of all logs as well as any wood products. This approach is unlike traditional sawmills that purchase 
logs either on an owner's property, from company land holdings, or 'at the gate.' Because the study logs were never owned by a wood processing company, customers instead paid separate fees for transport and processing of their logs into primary wood products, such as rough sawn boards. Customers were charged a per $\mathrm{km}$ (per loaded mile) transport fee from the customer's job site to the mill site in Dauphin County, Pennsylvania, in addition to a milling fee of USD \$0.18 per "board-foot," based on the estimated board-footage (or metric volume) of their logs. Generally, every log in this study would have likely gone into a dumpster or chip truck for disposal into a landfill, absent the treatment in this study. This is because the clients (job sites) were self-selected and were choosing this form of recycling rather than landfill disposal.

While the processor owns the only sawmill used to process study logs, labor for sawmill operations is subcontracted under this operating structure. Contracted sawyers were paid a flat fee for each board foot unit of rough sawn lumber produced regardless of species, dimension, or grade. During the study period, from January 2007 through March 2008, 21 separate job sites in five states and one territory (MD, NJ, NY, PA, VA, and D.C.) were self-identified by customers to the company. These 21 job sites represent every suburban and urban log recovery operation undertaken by this company in the geographic study area during the study period. The number of harvested logs at each of these job sites ranged from 1 to 29 and was comprised of hardwood, coniferous, and deciduous softwood species. Logs from each job site were treated and held separately at all stages of the study. Once at the mill site, each log was graded (Rast et al. 1973), and log diameters at each end, log length, and species were recorded. Prior to milling, the potential recoverable volume of each study log was scaled using the "international 1/4 inch Log Rule" (NHLA 2007).

All logs were visually inspected for signs of metal or other contamination prior to milling and then scanned with a White's
Classic IV Metal detector for remaining metallic contaminants. Additionally, during the milling process, all exposed faces were visually re-inspected and re-scanned for contaminants likely to be encountered in the next cut. Where metal contamination was encountered, those log sections were excised, measured and recorded, and the remaining sound log sections were re-scanned and milled.

All study logs were milled into green, rough-sawn, 4/4" (approximately $2.7 \mathrm{~cm}$ ) lumber of various lengths using a small diesel-powered sawmill (Mighty-Mite Circular Mill, Model D$812 \mathrm{H})$. Rough-sawn green boards were then evaluated for quality and defects and assigned as No. 1, No. 2, or No. 3 Common, according to published standards for hardwood lumber grading (NHLA 2007). The volume of slabs, cull sections, and sawdust was determined by subtracting the observed lumber recovery from the estimated log volume. The LRF was determined by dividing the observed lumber volume by the scaled lumber volume.

For logs obtained from each job site, the value of avoided disposal was calculated by estimating green weight by species (USDA FS Wood Handbook 1987) and material volume, multiplied by an average local landfill (municipal disposal area) fee. These value estimates were compared with the cost of transport to the mill site to yield the value of avoided disposal at each job site (Table 1). The difference in cost between landfill disposals versus hauling to the study mill for value-added processing was described by the following generalized equation:

$$
\left\{\mathrm{R}_{\mathrm{dv}}\left(2.2 \mathrm{~V}_{\mathrm{l}}\right)+\mathrm{R}_{\mathrm{dw}}\left(\mathrm{W}_{1}\right)\right\}-\left\{\mathrm{M}_{1}\left(\mathrm{R}_{\mathrm{h}}+\mathrm{f}_{\mathrm{s}}\right)\right\}=\mathrm{Cr}
$$

where $\mathrm{V}_{1}=$ total $\log$ volume $\left(\mathrm{m}^{3}\right)$ and 2.2 is an empirically derived correction factor for the average air gap when the material is containerized, $\mathrm{W}_{\mathrm{l}}=$ total $\log$ weight $\mathrm{t}$ (tonnes), $\mathrm{R}_{\mathrm{dv}}=$ volumetric landfill disposal rate $\left(\mathrm{USD} \$ / \mathrm{m}^{3}\right), \mathrm{R}_{\mathrm{dw}}=$ overweight landfill disposal rate (\$/t over base-t/load), $\mathrm{M}_{1}=$ loaded distance to mill $(\mathrm{km}), \mathrm{R}_{\mathrm{h}}=$ haul-

Table 1. Job sites, locations, and dates showing the avoided cost of disposal and hauling cost to the mill for each job. In equation (1), $R_{d v}+R_{d w}=$ cost of disposal, and $R_{h}+f_{s}=$ hauling cost; where $R_{d v}$ is the volumetric landfill disposal rate, $R_{d w}$ is the overweight landfill disposal rate, $\mathrm{Rh}$ is the hauling rate per mile, and $f_{s}$ is the fuel surcharge. Currency is represented in $U . S$. dollars.

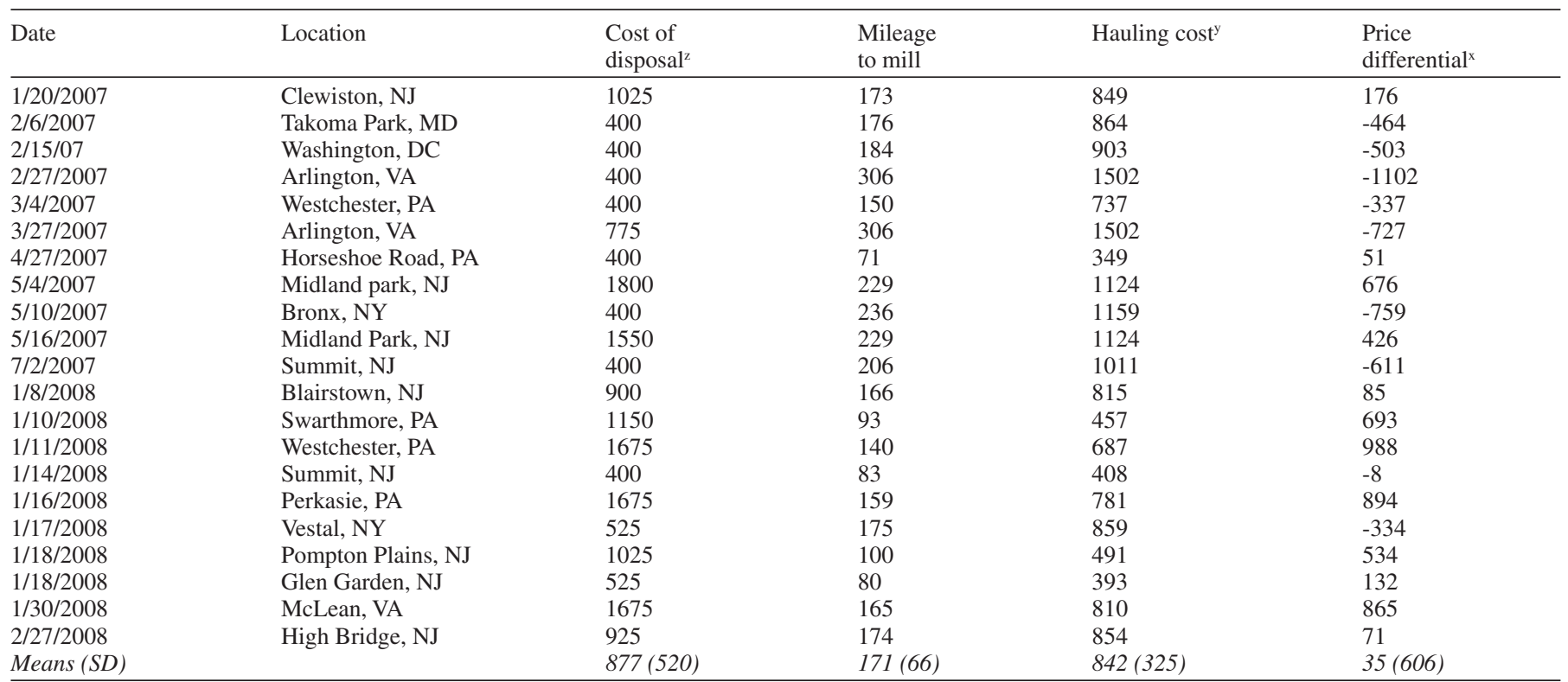

${ }^{\mathrm{z}}$ Cost of disposal assuming $\$ 400 / 40 \mathrm{yd}$. container rounded up to $40 \mathrm{yd}$. units, $\$ 125 /$ ton over seven tons.

y CitiLog charge per loaded mile, including fuel surcharge (subject to change) was $\$ 4.91$.

${ }^{\mathrm{x}}$ Price differential $=($ avoided disposal - realized hauling cost $)$. 
ing rate to mill $(\$ / \mathrm{km}), \mathrm{f}_{\mathrm{s}}=$ fuel surcharge $(\$), \mathrm{Cr}=$ marginal difference between hauling for mill processing and landfill disposal (\$).

An additional interest of this study was to analyze the efficiency of the business model in comparison to a traditional, procurement-driven and continuously operating sawmill. The analysis considered traditional sawmill operation costs including labor and log procurement.

\section{RESULTS AND DISCUSSION}

\section{Value of Avoided Disposal}

It was reported by the landowners in this study that very few of these urban logs would have been salvaged for firewood and instead landfilled as waste (D. Warmbold, pers. comm.). To the extent this was the case, the value of avoided disposal contributed significantly to the economic rationale of recovering urban logs. Due to common modes of log disposal in the study area (i.e., in fixed dumpsters) this value of avoided disposal was a function of both log volume and log weight. The quoted costs for disposal from different states and counties near job sites were surprisingly similar at the time of the study (P. LaMana, pers. comm.), and so for this analysis a standard disposal cost of $\$ 400$ per 40 yard container $\left(30.6 \mathrm{~m}^{3}\right)$, rounded up to 40 yard units, and $\$ 125$ per ton over seven tons, was used. Weight varied significantly depending on species (Table 2). Hardwood would have been more expensive to dispose of than conifers because of higher density, but the costs to mill both are equivalent at $\$ 0.18$ per board foot to the client. Additionally, hardwood lumber is usually more valuable as both a primary and secondary product, although the marginal difference in value between hardwood versus softwood products decreases as the value-added via secondary processing increases (e.g., flooring, moldings, cabinetry). These considerations are compared with the cost of hauling to the mill, which is primarily a function of distance multiplied by a fixed rate and a fuel surcharge.

Mean avoided disposal cost per job site was $\$ 877$ (95\% confidence interval for mean $=\$ 236.85$, range $=\$ 400$ to $\$ 1800, \mathrm{n}=$ 21 job sites). Alternatively, the mean cost to the customer of hauling these logs to the mill was $\$ 842$ (95\% confidence interval for mean $=\$ 147.92$, range $=\$ 348$ to $\$ 1502, \mathrm{n}=21$ job sites $)$. Thus, the mean marginal difference to the client was $\$ 35$ (95\% confidence interval for mean $=\$ 275.98$, range $=\$-1102$ to $\$ 988, \mathrm{n}=$ 21 job sites). This does not include milling costs and subsequent production of secondary products charged to the client as fee-forservice. These results varied considerably by species (Table 2 ). In general, hardwood is denser and more expensive to dispose of than softwood, but yields wood products of higher value. However, the marginal difference in disposal fees between hardwoods and softwoods is more than offset by the marginal retail value difference of rough-sawn lumber produced, which for softwood may be low.

\section{Recovery of lumber}

In this study, a total $313 \operatorname{logs}$, comprised of 12 species from 21 job sites, were taken to the study mill. Most of the recovered urban logs in this study were useable for the production of No. 1 and No. 2 common grade rough-sawn boards, and as reported, all lumber produced from study logs was comprised of these two grades (CitiLog, Inc.). Lumber recovery was surprisingly consistent among species and job sites. The total log volume (221.69 $\mathrm{m}^{3}$ ) yielded $103.57 \mathrm{~m}^{3}$ of lumber $(46.7 \%)$ and $118.12 \mathrm{~m}^{3}$ of waste; comprised of slabs, sawdust, rot, and metal contaminants. Among all logs and job sites, the normalized total $103.57 \mathrm{~m}^{3}$ $(43,891 \mathrm{BF})$ of approximately $2.7 \mathrm{~cm}$ thick (4/4") green lumber was produced, equating to an average LRF of $81.2 \%$ (95\% confidence interval for mean $=3.72 \%$, range $0 \%$ to $127 \%, \mathrm{n}=313$ $\operatorname{logs}$ ) (Table 2). Calculating the LRF as a percentage of the realized versus predicted lumber recovery describes the quality and condition of the wood. On average, approximately $81 \%$ of the predicted recoverable volume of study logs from scaling was captured and converted to primary wood products. In this study, logs derived from harvested urban and suburban trees provided a large volume of No. 1 and No. 2 common grade rough-sawn lumber.

\section{Contaminants}

There were logs containing metal contaminants from 7 of 23 job sites $(30 \%)$. The species of logs containing metal were pine Pinus spp., red oak (Quercus rubra), black oak ( $Q$. velutina), and poplar (Liriodendron tulipifera). From these job sites, 41 of 313 study logs contained some metal contamination (13\%). However, one job site was a yard clean-out where all logs taken were self-selected by the owner as low grade. All of the $\operatorname{logs}(n=18)$ from this single site contained metal contaminants and all were red oak. When this single site was excluded from the analysis, $23 \operatorname{logs}(8 \%)$ of the new total $(\mathrm{n}=$ 295) contained metal. The study authors observed no particular patterns correlating contamination with tree size or species.

\section{Value of Forest Products}

As described above, $103.57 \mathrm{~m}^{3}$ of green lumber were recovered from $313 \operatorname{logs}$ derived from urban and suburban trees. Based on average local market values at the time of the study, and the observed quality of sawn lumber, researchers assumed published wholesale values for green rough-sawn lumber as indicated for No. 2 lumber for each species sawn (HMR, 2/16/2008). It was estimated that this rough-sawn green lumber equated to a total value of $\$ 18,061.78$ at the time of the study. This valuation is conservative because there was some No. 1 quality lumber produced.

Assuming a wholesale value of $\$ 70$ per cord $\left(3.62 \mathrm{~m}^{3}\right)$, it was estimated that culls, slabs, and cutoffs represented approximately $\$ 2,461.65$ in salable firewood at the mill site. The study authors estimated that the $313 \log$ s used in the sawmill study would have been worth $\$ 4,440.78$ if used only as firewood, processed at the originating job sites. In this study, it was found that log processing and transportation revenues were additive, resulting in salvaged logs yielding a total value of $\$ 20,523$ at the mill location versus approximately $\$ 4,440$ of value at the job sites (an increase of $462 \%$ ) after accounting for the cost of transportation and the value of avoided disposal.

\section{Business Model}

A traditional business model in this case has two basic cost components: log procurement and operational. However, in this study, log procurement costs are not applicable because this business model does not procure logs from owners. This case study examined a fee-for-service model wherein the milling entity owns neither the logs (procurement costs are irrelevant) nor the resulting products. Categories of operational costs are fewer. 
Table 2. Disposal parameters used in calculating values of avoided disposal, and observed average lumber recovery and inferred values of study logs.

\begin{tabular}{|c|c|c|c|c|c|c|c|}
\hline Tree species & $\begin{array}{l}\text { Number of } \\
\text { study logs }\end{array}$ & $\begin{array}{l}\text { Mean }(\mathrm{SD}) \text { per } \\
\text { log volume }\left(\mathrm{m}^{3}\right)\end{array}$ & $\begin{array}{l}\text { Mean }(\mathrm{SD}) \text { per log } \\
\text { green weight (tonnes) }{ }^{\mathrm{z}}\end{array}$ & $\begin{array}{l}\text { Mean BF (SD) per } \\
\text { log lumber produced }\end{array}$ & $\begin{array}{l}\text { Mean }(\mathrm{SD}) \text { per log } \\
\text { lumber recovery } \\
\text { factor }^{x}\end{array}$ & $\begin{array}{l}\text { Mean (SD) per } \\
\text { log firewood } \\
\text { value }^{w}\end{array}$ & $\begin{array}{l}\text { Mean (SD) per log } \\
\text { lumber value }^{v}\end{array}$ \\
\hline Ash - Fraxinus spp. & 27 & $\begin{array}{l}1.08 \\
(0.6)\end{array}$ & $\begin{array}{l}0.86 \\
(0.48)\end{array}$ & $\begin{array}{l}240.4 \\
(143.4)\end{array}$ & $\begin{array}{l}90.9 \\
(12.6)\end{array}$ & $\begin{array}{l}21.02 \\
(11.5)\end{array}$ & $\begin{array}{l}836 \\
(618)\end{array}$ \\
\hline Aspen - Populus spp. & 12 & $\begin{array}{l}0.37 \\
(0.13)\end{array}$ & $\begin{array}{l}0.25 \\
(0.1)\end{array}$ & $\begin{array}{l}66.8 \\
(34.67)\end{array}$ & $\begin{array}{l}92.8 \\
(17.4)\end{array}$ & $\begin{array}{l}7.13 \\
(2.59)\end{array}$ & $\begin{array}{l}18.8 \\
(9.36)\end{array}$ \\
\hline Hickory - Carya spp. & 2 & $\begin{array}{l}0.65 \\
(0.14)\end{array}$ & $\begin{array}{l}0.66 \\
(0.15)\end{array}$ & $\begin{array}{l}147.5 \\
(38.13)\end{array}$ & $\begin{array}{l}98.1 \\
(2.26)\end{array}$ & $\begin{array}{l}33.25 \\
(19.8)\end{array}$ & $\begin{array}{l}585.25 \\
(100.4)\end{array}$ \\
\hline Maple (hard) - Acer spp. & 16 & $\begin{array}{l}0.87 \\
(0.44)\end{array}$ & $\begin{array}{l}0.7 \\
(0.36)\end{array}$ & $\begin{array}{l}66.3 \\
(95.2)\end{array}$ & $\begin{array}{l}44.1 \\
(46)\end{array}$ & $\begin{array}{l}22.6 \\
(14.13)\end{array}$ & $\begin{array}{l}246.8 \\
(357)\end{array}$ \\
\hline $\begin{array}{l}\text { Oak (black) - Quercus } \\
\text { velutina }\end{array}$ & 12 & $\begin{array}{l}0.81 \\
(0.18)\end{array}$ & $\begin{array}{l}0.79 \\
(0.18)\end{array}$ & $\begin{array}{l}165.3 \\
(61.08)\end{array}$ & $\begin{array}{l}92.3 \\
(23.8)\end{array}$ & $\begin{array}{l}14 \\
(4.12)\end{array}$ & $\begin{array}{l}700.19 \\
(259.58)\end{array}$ \\
\hline Oak (red) - Q. rubra & 132 & $\begin{array}{l}0.72 \\
(0.4)\end{array}$ & $\begin{array}{l}0.71 \\
(0.39)\end{array}$ & $\begin{array}{l}134.8 \\
(114.65)\end{array}$ & $\begin{array}{l}83.2 \\
(35.6)\end{array}$ & $\begin{array}{l}15.69 \\
(8.49)\end{array}$ & $\begin{array}{l}476.27 \\
(421.54)\end{array}$ \\
\hline Oak (white) - Q. alba & 18 & $\begin{array}{l}0.93 \\
(0.39)\end{array}$ & $\begin{array}{l}0.94 \\
(0.4)\end{array}$ & $\begin{array}{l}182.2 \\
(87.47)\end{array}$ & $\begin{array}{l}86.4 \\
(25)\end{array}$ & $\begin{array}{l}31.18 \\
(12.58)\end{array}$ & $\begin{array}{l}715.85 \\
(346.06)\end{array}$ \\
\hline Pine - Pinus spp. & 23 & $\begin{array}{l}0.25 \\
(0.08)\end{array}$ & $\begin{array}{l}0.21 \\
(0.06)\end{array}$ & $\begin{array}{l}28.7 \\
(26.26)\end{array}$ & $\begin{array}{l}64.7 \\
(46.5)\end{array}$ & $\begin{array}{l}4.76 \\
(1.45)\end{array}$ & $\begin{array}{l}8.07 \\
(7.09)\end{array}$ \\
\hline $\begin{array}{l}\text { Poplar - Liriodendron } \\
\text { tulipifera }\end{array}$ & 41 & $\begin{array}{l}1.02 \\
(0.39)\end{array}$ & $\begin{array}{l}0.62 \\
(0.24)\end{array}$ & $\begin{array}{l}225.3 \\
(95.82)\end{array}$ & $\begin{array}{l}93.8 \\
(17.8)\end{array}$ & $\begin{array}{l}19.73 \\
(7.55)\end{array}$ & $\begin{array}{l}129.4 \\
(88.26)\end{array}$ \\
\hline $\begin{array}{l}\text { Walnut (black) - } \\
\text { Juglans nigra }\end{array}$ & 3 & $\begin{array}{l}0.29 \\
(0.08)\end{array}$ & $\begin{array}{l}0.27 \\
(0.08)\end{array}$ & $\begin{array}{l}29 \\
(11.53)\end{array}$ & $\begin{array}{l}49.5 \\
(6)\end{array}$ & $\begin{array}{l}5.6 \\
(1.56)\end{array}$ & $\begin{array}{l}7.83 \\
(3.11)\end{array}$ \\
\hline
\end{tabular}

${ }^{\mathrm{z}}$ Green weights inferred from estimated total volume and published values for green log densities (USDA 1987).

y International 1/4" rule.

${ }^{\mathrm{x}}$ Actual recovery V. log rule estimate.

w Commercial value estimated as cords of salable firewood, assuming price of $\$ 70$ per cord.

${ }^{v}$ Realized log value based on actual average lumber recovery and assumed wholesale lumber values.

For example, in some cases there can be a cost to disposal of materials such as chips, sawdust, and bark, making those products an unwanted waste product rather than a produced good.

As is common with small mobile mills in the study area versus large fixed-site facilities, the authors found that there is a single mill operator working as an independent contractor for a unit fee per board-foot. Also, because the business (in this case Citilog, Inc.) owns and operates a small, mobile mill, the cost of downtime is essentially zero. In comparison with continuously operated, procurement mill operations predicated on traditional inputs and outputs, small mill operations in urban settings differ significantly in both structure and function. For these reasons, a business structure with fixed inputs of labor and materials and production outputs is not efficient with utilization of urban wood through production of value-added wood products. This is because, in this case study, an integrated firm depended on a fee-for-service business model to be profitable with small volumes of widely distributed logs. To be profitable, this business model required a customer base willing to contract the conversion of trees to wood products as an alternative to landfill or other disposal. Because the information was considered proprietary, the details of opera- tional and contracted labor costs of milling were not disclosed. However, the cost to the client for milling was $\$ 180$ per $2.36 \mathrm{~m}^{3}$ (1000 board-feet) based on scaled values at the job site. An analysis with simplified parameters that estimated the costs associated with subcontracted sawyer-labor, operation, and maintenance (excluding capital depreciation on the mill itself) suggests a relatively low profit margin from the mill operation itself. As reported by the mill company, profitability required there be no log procurement costs and a guaranteed market for all lumber produced, thus the fee-for-service model rather than a fee-for-product model.

\section{CONCLUSIONS}

In this study, researchers show that on average the cost of hauling $\operatorname{logs}$ to a mill for conversion to wood products is nearly offset by the avoided cost of log disposal in municipal landfills. Assuming that saving money was a primary consideration in the decision to either mill urban logs or divert them to a landfill, approximately net zero cost/benefit in hauling versus disposal to the customer was observed. However, this does not include subsequent fees to the client for converting trees into primary and secondary forest 
products. This business model can be considered as an integrated entity with respect to log procurement (hauling and milling). Neither is profitable as a stand-alone entity in this case because the trucking operation is approximately break-even and the mill operation requires a near zero log procurement cost to be profitable.

A non-monetary aesthetic value (e.g., Gopalakrishnan et al. 2011) can be placed on using site-derived tree products such as flooring and cabinetry, and in this case study the company demonstrated a profitable basis for this particular form of valuation. One permutation of this aesthetic valuation, as reported by clients, was that the actual lumber grade was a misleading indicator of value to the client, because lower grade boards often had "more interesting" grain structures that yield higher value secondary products (D. Warmbold, pers. comm.). Additionally, there is a considerable value to the community of reducing pressure on landfill space and other public resources. These sorts of hedonic or perceived values accrued by the client or end user are represented by the milling and additional costs for production of secondary products. The study authors believe stakeholders, including municipalities, builders, landowners, and public institutions, can reasonably consider, and may incentivize, these sorts of urban wood utilization strategies to a greater extent in the future.

Acknowledgments. The authors thank E. Cesa, A. Steele (USDA Forest Service - Wood Education and Resource Center) and E. Lempicki (NJ Forest Service) for their helpful suggestions and support; and D. Warmbold, Citilog, Inc., and P. LaMana, Heartwood Consulting, for help with data collection. Additionally, we thank two anonymous reviewers. This study was funded in part from a grant by the Wood Education and Resource Center, Northeastern Area State and Private Forestry, Forest Service, U.S. Department of Agriculture.

\section{LITERATURE CITED}

Bratkovich, S.M. 2001. Utilizing Municipal Trees: Ideas from Across the Country. NA-TP-06-01, St. Paul, MN: USDA, Forest Service, Northeastern Area, State and Private Forestry.

Cesa, E.T., E.A. Lempicki, and J. H. Knotts. 1994. Recycling Municipal Trees: A Guide for Marketing Sawlogs from Street Tree Removals in Municipalities. NA-TP-02-94, Morgantown, WV: USDA, Forest Service, Northeastern Area, State and Private Forestry.

Gopalakrishnan, S., M.D. Smith, J.M. Slott, and A.B. Murray. 2011. The value of disappearing beaches: A hedonic pricing model with endogenous beach width. Journal of Environmental Economics and Management 61:297-310.

Gorman, J. 2004. Resident's opinions on the value of street trees depending on location. Journal of Arboriculture 30:36-44.

Hardwood Market Report, Vol. 86, No. 7, February 16, 2008. Hardwood Market Report, P.O. Box 2633, Memphis, Tennessee, U.S.
Lempicki, E.A., and E.T. Cesa. 2000. Recycling urban tree removals, pp. 359-374. In: J.E. Kuser (Ed.). Handbook of Urban and Community Forestry in the northeast. New York: Kluwer Academic/Plenum Publishers. 444 pp.

MacFarlane, D.W. 2007. Quantifying urban saw timber abundance and quality in southeastern lower Michigan, U.S. Journal of Arboriculture 33:253-263.

Matheny, N.P., and J.R. Clark. 1994. A Photographic Guide to the Evaluation of Hazard Trees in Urban Areas. 2nd edition. International Society of Arboriculture, Urbana, Illinois, U.S.

McPherson, E.G., James R. Simpson, and Paula J. Peper. 2005. Municipal forest benefits and costs in five U.S. cities. Journal of Forestry 103:411-416.

NHLA. 2007. Rules for the Measurement \& Inspection of Hardwood \& Cypress, Plus NHLA Sales Code \& Inspection Regulations, Effective January 1, 2007. National Hardwood Lumber Association, PO Box 34518, Memphis, TN 38184-0518.

Nowak, D.J., J.T. Walton, J.F. Dwyer, L.G. Kaya, and S. Meyong. 2006. The increasing influence of urban environments on U.S. forest management. Journal of Forestry 103:377-382.

Pataki, D.E., R.J. Alig, A.S. Fung, N.E. Golubiewski, C.A. Kennedy, et al. 2006. Urban ecosystems and the North American carbon cycle. Global Change Biology 12:2092-2102.

Rast, E.D., D.L. Sonderman, and G.L. Gammon. 1973. A Guide to Hardwood Log Grading. Gen. Tech. Rep. NE-1. Upper Darby, PA: U.S. Department of Agriculture, Forest Service, Northeastern Forest Experiment Station. $32 \mathrm{pp}$.

Sabor, A.A., V.C. Radeloff, R.B. Hammer, and S.I. Stewart. 2003. Relationship between housing density and timber harvest in the Upper Lake States, pp. 80-82. In: L.J. Buse, A.H. Perera, comps. Meeting emerging ecological, economic, and social challenges in the Great Lakes region: Popular summaries. For. Res. Inf. Pap. 155. Sault Ste. Marie, ON: Ontario Ministry of Natural Resources, Ontario Forest Research Institute.

Sherrill, S.B. 2003. Harvesting Urban Timber: A Guide to Making Better Use of Urban Trees. Linden Publishing Inc., Fresno, California, U.S. $223 \mathrm{pp}$.

USDA Forest Service Forest Products Lab. 1987. Wood Handbook: Wood as an engineering material. Agriculture Handbook 72, Washington, D.C., U.S. 466 pp.

Craig A. Tinus (corresponding author)

Department of Forest Ecosystems and Society

Oregon State University

Corvallis, Oregon 97330, U.S.

craig.tinus@oregonstate.edu

Michael LaMana

Heartwood Ecological Consulting

1561 Rt. 9, Ste. 6

Toms River, New Jersey 08753, U.S. 
Résumé. En raison des changements dans l'usage des terrains, plusieurs activités de gestion forestières ne peuvent plus être réalisées au sein de propriétés boisées en milieux urbain et périurbains qui ont été construites. Cette situation a créé un afflux de fibres de bois au sein des sites de dépôts municipaux occasionnant des coûts significatifs à la fois pour les propriétaires et les municipalités. Une alternative à la disposition dans les sites de dépôts et autres sites a été évaluée afin de retourner les produits du bois aux propriétaires au moyen d'un modèle d'affaire de frais de service. De plus, le coût pour l'enlèvement a été modélisé en comparaison avec la valeur potentielle du bois en tant que bois d'œuvre. Dans une étude cas, la différence marginale moyenne totale au propriétaire pour l'enlèvement des matériaux se chiffrait à un coût de $35 \$$ U.S. pour l'ensemble des activités sur le terrain $(n=21)$; cela s'avérait essentiellement être le point d'équilibre. Cette approche était compétitive en terme de coût avec la disposition dans un site de dépôt et les propriétaires étaient capables de tirer bénéfice des produits dérivés du bois des arbres qui avaient été enlevés en raison du développement des propriétés. Enfin, ces propriétaires choisissaient préférablement une forme de recyclage des matériaux qui permettait de réduire la charge vers les sites de dépôt municipaux, ce qui constituait dès lors un bénéfice pour la communauté.

Zusammenfassung. Wegen der Veränderungen in der Landnutzung sind viele forstlichen Standardaktivitäten in urbanen und in Entwicklung befindlichen suburbanen waldigen Gebieten nicht mehr möglich. Dieser Trend schafft einen Zuwachs an Holzfaser in kommunale Bodenverfüllungen, die signifikante Kosten für Landbesitzer und kommunaler Behörden nach sich ziehen. Eine Alternative zur Bodenverfüllung oder andere Lagerung wurde hier bewertet, die Holzprodukte zu dem Landeigentümer zurückführt in Form eines Gebühren-gegen-Service Geschäfts- modells. Zusätzlich wurden die Kosten für die Entfernung modellhaft im Vergleich zu dem potentiellen Wert des Holzes als Baustoff verglichen. In einer Fallstudie betrugen die durchschnittlichen Differenzen, die der Landbesitzer an Kosten für die Materialbeseitigung aufwenden muss, $\$ 35$ an allen Standorten $(n=21)$, was in etwa den Deckungspunkt darstellt. Dieser Ansatz war kostengleich mit der Bodenverfüllung und die Landeigentümer waren so in der Lage, von den Holzprodukten, die von dem nun erschlossenen Standort stammen, zu profitieren. Zusätzlich bevorzugten die Landbesitzer hier eine Form der Materialrückgewinnung, die die Last auf kommunalen Entsorgungsstätten reduziert und damit den Kommunen zum Vorteil gereicht.

Resumen. Debido a los cambios en uso del suelo, muchas actividades estándar de manejo del bosque no son ya posibles en propiedades urbanas y suburbanas que están en desarrollo. Esto tiende a crear un influjo de fibra de madera en rellenos municipales a costos significativos tanto en propietarios de terrenos y municipalidades. Una alternativa para rellenar o disponer de otros sitios fue evaluada para los productos de la madera a los propietarios en un modelo de negocios por una cuota por servicio. Adicionalmente, el costo por remoción fue modelado en comparación al valor potencial de la madera. En un caso de estudio, la diferencia promedio marginal total al propietario para remoción de material fue a un costo de USD $\$ 35$ de todos los sitios de trabajo $(n=21)$. Esta aproximación fue un costo competitivo para disposición de relleno, y los propietarios se pudieron beneficiar de productos de madera derivados de árboles que estuvieron siendo removidos debido al sitio de desarrollo. Adicionalmente, estos propietarios estuvieron preferencialmente escogiendo una forma de material de reciclaje que parece más reducido que la carga a sitios de desecho municipales, y como tal fue benéfico para la comunidad. 